\section{GUTTA-PERCHA AND INDIA-RUBBER}

BOTANISTS who are interested in the cultivation of Sapotacea on a commercial scale, are beginning to realise the consequences of the careless methods that have denuded the Indo-Malayan regions of Taban trees. Cable-manufacturers complain very seriously of the great falling-off in quality of gutta-percha during the past few years, and the small hope of obtaining better supplies in future. This degeneration of the cultivating industry is beginning to make itself felt in the Treasury Reports of the gutta-percha producing countries; not so much in the quantity annually shipped, as in the prices paid for a given weiglit each year.

For instance, the Sarawak (Borneo) Treasury Report of revenue and expenditure for I 897 gives comparative figures relating to the condition of supply and demand of gutta-percha and india-rubber; the following table, drawn up from the Report, shows the fall in prices of gutta-percha during the four years 1894-1897, inclusive, and indicates a corresponding degradation of quality. (The "picul" is, for our purpose, taken as $133 \frac{1}{3}$ lbs., and the Sarawak dollar as is. I $d$.)

Gutta-percha exported from Sarawak.

\begin{tabular}{|c|c|c|c|c|c|c|}
\hline Year. & \multicolumn{2}{|c|}{ Quantity. } & \multicolumn{2}{|c|}{ Value. } & \multicolumn{2}{|c|}{$\begin{array}{l}\text { Average price } \\
\text { per picul. }\end{array}$} \\
\hline & Piculs. & Tons. & & s. $d$. & $\$$ & $s$ \\
\hline I 894 & 1937 & 1153 & 162,233 & 15,54767 & 83.75 & 0 61 \\
\hline I895 & 2782 & 165.6 & 194,120 & 18,60334 & 69.77 & $\begin{array}{lll}6 & 13 & 83 \\
4\end{array}$ \\
\hline 1896 & 2820 & 1679 & 190,939 & 18,29865 & 6770 & $\begin{array}{lll}6 & 9 & 9\end{array}$ \\
\hline 1897 & 2867 & $170 \%$ & 185,532 & 17,78030 & 6471 & $40 \frac{1}{2}$ \\
\hline
\end{tabular}

With this may be compared the increased demand for, and steady value of india-rubber throughout the same period.

India-rubber exported from Sarawak.

\begin{tabular}{|c|c|c|c|c|c|c|c|}
\hline \multirow{2}{*}{$\begin{array}{l}\text { Year. } \\
\text { I } 894\end{array}$} & \multicolumn{2}{|c|}{ Quantity. } & \multicolumn{3}{|c|}{ Value. } & \multicolumn{2}{|c|}{$\begin{array}{l}\text { Average price } \\
\text { per picul. }\end{array}$} \\
\hline & $\begin{array}{l}\text { Piculs. } \\
\text { I250 }\end{array}$ & Tons. & 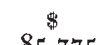 & s & s. $d$. & $\$$ & $\notin s . \quad d$. \\
\hline $\begin{array}{l}1894 \\
1895\end{array}$ & $\begin{array}{l}1259 \\
1392\end{array}$ & $\begin{array}{l}749 \\
82.8\end{array}$ & $\begin{array}{l}85,775 \\
95,493\end{array}$ & $\begin{array}{l}8,220 \\
9,151\end{array}$ & $\begin{array}{ll}2 & 1 \\
8 & 3\end{array}$ & $\begin{array}{l}68 \cdot 12 \\
68 \cdot 60\end{array}$ & $\begin{array}{llll}6 & 10 & 63 \\
6 & \text { II } & 5 \frac{3}{4}\end{array}$ \\
\hline 1896 & 1624 & $96 \cdot 7$ & 108,8 I 3 & 10,427 & I 83 & 67.00 & $685^{34}$ \\
\hline I 897 & 2130 & 126.8 & 146,229 & 14,013 & 123 & $68 \cdot 65$ & 6 II 7 \\
\hline
\end{tabular}

From another source we are able to give the total weights of gutta-percha landed in England, from all gutta-percha producing countries, since 1895 .

Total Weight of Gutta-percha landed in England.

Year.

1895

1896

$\begin{array}{llllllll}\mathbf{1} 896 & \ldots & \ldots & \ldots & \ldots & \ldots & \ldots & 3 \text { I } 8 \\ \text { I } 897 & \ldots & \ldots & \ldots & \ldots & \ldots & \ldots & 396\end{array}$

The present year shows a very marked rise in the demand for gutta-percha ; this is more apparent when it is remembered that the 626 tons was all landed between January I and April 30 , and that the quantity landed in April alone was I49 tons.

We may sum up the condition of the gutta-percha cultivation industry in a few words: there is an increasing demand, a degeneration of quality, and an almost total disregard of the future. Experimental efforts have, we believe, been made to produce a steady supply of high-quality gutta-percha, but so many years are required to establish the scheme on a profitearning basis, that it is almost beyond the powers of privale enterprise to make it a success.

\section{TREATMENT OF THE SURFACE OF $M E D A L S{ }^{1}$ \\ SiLVER.}

I $\mathrm{N}$ this country medals have been issued for centuries with the tables or flat surfaces smooth and mirror-like, while a more or less frosted texture has been given to the portions in relief. This is especially the case in medals which have been struck as

1 From a memorandum by Prof. Roberts-Austen, C.B., F.R.S., in the Twenty-eighth Annual Report of the Deputy Master and Comptroller of the Mint, 1897 .

NO. I497, VOL. 58] specimen pieces, for after highly-polished dies have been used for a certain time the difference between the appearance of the tables and the parts in relief becomes less and less marked. As is well known, medals with polished surfaces rapidly tarnish, and even blacken, by exposure to the ordinary atmospheric influences. In France a different system has long been adopted concurrently with the one just described. Unpolished dies are employed, and care is taken to impart to the medals struck from them a dead or frosted surface by rubbing them with fine pumice. Recently, at the French Mint, medals have been sub. jected to the process known as "sand blasting" by the aid of an appliance which projects against the surface of the medal a small jet of air, carrying with it fine sand, and having a velocity of about i 80 feet per second. When thus treated the surface of the medal becomes minutely granular or frosted, and may then be further treated in several ways. Sometimes the surface is darkened by exposure to an aqueous solution of a sulphide, followed by rubbing with very fine pumice, which removes the dark layer of sulphide from the portions in high relief, and leaves dark lines in the more deeply-cut recesses. It is, however, preferable to cover the medal with a layer of platinum, and this is effected by immersing it in an alcoholic solution of chloride of platinum until a blackened surface is produced. Subsequent rubbing with a brush and very fine pumice changes the blackened surface to a delicate grey; and if this operation is conducted skilfully, graduated shadows may be left wherever the artist considers their presence to be desirable. The beauty of medals so treated, and the fidelity with which the details of the design are revealed, are beyond question; but it may be doubted whether the surface of the medal is permanently protected. A medal with a frosted platinised surface has, however, a great advantage over one with a polished table, as the platinised medal is merely deepened in tone by exposure to the atmosphere, and, unlike medals which have been struck in the ordinary way, does not become disfigured by blotches of tarnish. The frosted platinised medal may be restored to almost its original freshness by careful rubbing with a soft leather; while a polished silver one cannot be so renovated, as the tarnish attacks the surface and destroys the polish.

During the past year, for the first time in the history of the Mint, medals have been issued with frosted and platinised surfaces. More than 27,000 large silver medals were platinised by a slight modification of the above method. It became necessary, therefore, to provide an appliance for producing the sand blast, and this, together with a small I H.P. motor for driving it, has been fitted up in the basement of the Assay Department.

\section{BRONZE.}

Medals of bronze differ considerably from those of silver, as their surfaces are far more liable to be influenced either by the slow operation of the constituents of the atmosphere or by the more rapid action of chemical agents. Ancient silver coins, for instance, which have been long buried in the earth, do not show anything like so wide a range of colour in their patina or crust, as is revealed on coins of brass, bronze or copper, which have been hidden in the same way. This is due to the fact that silver is far less affected than copper by the chemical action of the constituents of soils, or by atmospheric influences. The patina acquired by an ancient coin or medal often constitutes no small part of its value. "You would laugh at me," said Philander, in Addison's charming dialogues upon the usefulness of ancient medals, " should I make you a learned dissertation on the nature of rusts; I shall only tell you that there are two or three sorts of them which are extremely beautiful in the eye of the antiquary, and preserve a coin better than the best artificial varnish." The object of the medallist is accurately expressed in the above sentence, for he endeavours to protect the surface of all medals in which copper is the main constituent, by a patina or film of oxide, so as to preserve the medal from further change. This may be effected in various ways. The medals of the Italian Renaissance were not struck, but cast by the method of cera perduta, already described in these Reports, ${ }^{1}$ and much of the beauty of the medal was due to the "skin" or pellicle of oxide which the medal acquired during casting. The skill of the artist in arranging the composition of the bronze, and fixing the temperature at which it was cast, was revealed in the texture of the medal's surface.

In modern times most medals to which the name of bronze is given are really of copper, " bronzed" or coloured artificially on I Sixteenth Report (1886), pp. 24, 49; Seventeenth Report (x886), p. I5. 